\title{
Pembelajaran dengan Model Eliciting Activities (Meas) untuk Meningkatkan Kemampuan Penalaran
}

Lessa Roesdianaa), Nita Hidayatib)

a,b) Program Studi Pendidikan Matematika, Universitas Singaperbangsa Karawang Lessa.Roesdiana@yahoo.coma).

\begin{tabular}{l}
\hline \multicolumn{1}{c}{ Article Info } \\
\hline Kaywords : Learning with \\
Model Eliciting Activities \\
(MEAs), Mathematical \\
Reasoning Ability, Economic \\
Mathematics
\end{tabular}

Abstract
The purpose of this study is to analyze the achievement and the
improvement of college students mathematical reasoning abilities
that have learned with Model Eliciting Activities (MEAs) and
expository learning. This study used pretest-posttest control group
design with the population are 37 students in class IVD as an
experiment class and 38 students in class IVE as a control class. The
instrument that used in this study was mathematical reasoning test
with mathematical reasoning ability as the indicator and the
measured variable, included pretest, posttest and n gain score. Data
was analyzed by software SPSS version 22 for Windows, the results
of this study shows that the achievement and the improvement of
college students mathematical abilities that have learned with MEAs
is better than college students that have learned with expository
learning. So, it can be concluded that MEAs can improve
mathematics learning outcomes especially in Mathematicals
Economics course.


Kata Kunci:

Kemampuan penalaran

matematis, pembelajaran Model Eliciting Activities (MEAs), Matematika Ekonomi

\begin{abstract}
Abstrak
Tujuan penelitian ini adalah menelaah pencapaian dan peningkatan kemampuan penalaran matematis mahasiswa yang memperoleh pembelajaran Model Eliciting Activities (MEAs) dengan yang memperoleh pembelajaran ekspositori. Penelitian ini menggunakan desain penelitian pretest-posttest control group design, dengan populasi penelitiannya yaitu kelas eksperimen IVD terdiri 37 orang dan kelas kontrol IVE terdiri 38 orang. Instrumen tes mencakup tes kemampuan penalaran matematik dengan indikator dan variabel yang diukur adalah tingkat kemampuan penalaran matematis yang meliputi nilai pretest, posttest dan $\mathrm{n}$ gain. Data diolah menggunkan Software SPSS versi 22 for Windows, hasil penelitian ini menunjukkan bahwa pencapaian dan peningkatan kemampuan penalaran matematik mahasiswa yang memperoleh pembelajaran MEAs lebih baik dibandingkan dengan pembelajaran Ekspositori.Jadi dapat disimpulkan model pembelajaran MEAs dapat meningkatkan hasil belajar matematika khususnya mata kuliah Matematika Ekonomi.
\end{abstract}

\section{PENDAHULUAN}

Matematika adalah pola berpikir, pola mengorganisasikan, pembuktian yang logik, matematika itu adalah bahasa yang menggunakan istilah yang didefinisikan dengan cermat, jelas, dan akurat, representasinya dengan simbol dan padat, lebih berupa bahasa simbol mengenai ide daripada mengenai bunyi. Johnson dan Rising (Suherman et al, 2003: 17). Sejalan dengan hal tersebut, pada hakikatnya visi matematika memiliki dua arah pengembangan yaitu untuk memenuhi kebutuhan masa kini dan kebutuhan masa datang. Dimana salah satu visinya yaitu matematika memberikan kemampuan menalar yang logis (Sumarmo, 2013: 3). Berdasarkan pemaparan di atas, aspek penalaran merupakan salah satu kemampuan yang harus dimiliki mahasiswa. Oleh karena itu, dalam setiap proses pembelajaran matematika, Dosen diharapkan bisa menerapkan kemampuan penalaran.
Tugas Dosen juga mendorong berkembangnya pemahaman dan penghayatan terhadap prinsip, nilai dan proses matematika, dan menumbuhkan daya nalar, berpikir logis, sistimik, kritis, kreatif, cerdas, rasa keindahan, terbuka dan rasa ingin tahu siswa. Dengan kata lain, tugas Dosen matematika adalah membimbing siswa memiliki pengetahuan dan nilai mat ematika, melaksanakan proses berpikir matematik, serta menumbuhkan rasa senang dan cinta belajar matematika di kalangan mahasiswa (Sumarmo, 2013: 27). Mengingat perannya yang sangat penting dalam semua bidang ilmu, maka upaya peningkatan proses pembelajaran matematika yaitu dengan menitikberatkan pada kemampuan penalaran. Upaya ini menjadi sangat penting mengingat beberapa penelitian menunjukkan bahwa dalam mengerjakan soal-soal matematika, siswa kerap kali mengalami kesulitan terutama dalam proses nalar. 
Oleh karena itu, perlu adanya suatu metode pembelajaran yang dapat meningkatkan kemampuan penalaran matematis siswa. Salah satu metode yang dapat meningkatkan kemampuan penalaran matematis yaitu model eliciting activities (MEAs). MEAs adalah permasalahan yang disajikan dalam pembelajaran merupakan permasalahan yang realistik. Selain menyajikan permasalahan yang realistik, pembelajaran dengan pendekatan MEAs melibatkan aktivitas menciptakan model matematis, Zulkarnaen, R (2015). Dengan demikian, diharapkan pembelajaran ini dapat melatih siswa untuk menyajikan gagasan matematik dengan menerjemahkan masalah ke dalam bentuk matematis baik berupa model, pola, analogi, penalaran logis maupun menarik kesimpulan.

Dari uraian di atas mengangkat rumusan masalah, yaitu:

1. Apakah pencapaian kemampuan penalaran matematis mahasiswa yang pembelajarannya menggunakan Model Eliciting Activities (MEAs) lebih baik daripada yang menggunakan pembelajaran Ekpositori?

2. Apakah peningkatan kemampuan penalaran matematis mahasiswa yang pembelajarannya menggunakan Model Eliciting Activities (MEAs) lebih baik daripada yang menggunakan pembelajaran Ekpositori?

\section{METODE}

Model penelitian ini adalah quasi eksperimen. Pada penelitian ini digunakan dua kelas, kelas eksperimen dan kelas kontrol. Penelitian untuk kelas eksperimen menggunakan pembelajaran Model Eliciting Activities (MEAs) dan kelas kontrol dengan model pembelajaran ekspositori.

Tempat penelitian di Universitas Singaperbangsa Karawang Semester IV Program Studi Pendidikan Matematika. Sampel penelitian untuk kelas eksperimen yaitu kelas IV D terdiri 37 orang dan kelas kontrol yaitu kelas IV E terdiri 38 orang. Hal ini dipilih dengan pertimbangannya adalah pemilihan anak dalam suatu kelas tidak didasarkan atas rangking nilai tetapi secara acak oleh pihak peneliti dan semua kelas diberi pelajaran dengan kurikulum yang sama. Dari dua kelas tersebut diberikan perlakuan yang berbeda, yaitu model pembelajaran Model Eliciting Activities (MEAs) untuk kelas eksperimen dan pembelajaran ekspositori untuk kelas kontrol.

Fokus permasalahan dalam penelitian ini adalah Apakah pencapaian dan peningkatan kemampuan penalaran matematik mahasiswa yang pembelajarannya menggunakan pembelajaran Model Eliciting Activities (MEAs) lebih baik daripada yang menggunakan Pembelajaran Ekspositori?

Indikator penelitian adalah pencapaian dan peningkatan kemampuan penalaran matematik mahasiswa yang pembelajarannya menggunakan pembelajaran Model Eliciting Activities (MEAs) dibanding dengan yang menggunakan pembelajaran Ekspositori dan variabel yang diukur meliputi skor 
pretes, postes dan n-gain dalam tes kemampuan penalaran matematik.

Seluruh data dalam penelitian ini diolah dengan menggunakan SPSS dengan langkah-langkah sebagai berikut:

1. Menghitung rata-rata, variansi dan simpangan baku data hasil pretes dan postes kelas eksperimen dan kelas kontrol.

2. Melakukan uji normalitas dari data hasil pretes dan postes kelas eksperimen dan kelas kontrol serta gain.

3. Melakukan uji homogenitas varians dengan uji $\mathrm{F}$.

4. Melakukan uji signifikansi perbedaan dua rata-rata dengan uji t jika data berdistribusi normal atau uji mann whitney jika data tidak berdistribusi normal.

5. Mengolah data kualitas peningkatan yang diperoleh dengan indeks gain. Menghitung besarnya peningkatan kemampuan komunikasi dan penalaran matematik siswa (gain) yang diperoleh dari skor pretes dan postes dengan menggunakan gain ternormalisasi yang dikembangkan oleh Hake (Aini, 2013:40).

\section{HASIL DAN PEMBAHASAN Hasil Penelitian}

Data yang diolah dan dianalisis pada penelitian ini berupa skor pretes, posttes, gain ternormalisasi untuk kemampuan penalaran matematik mahasiswa terhadap pembelajaran Model Eliciting Activities (MEAs). Berikut ini disajikan statistik deskriptif skor pretes, posttes, dan gain ternormalisasi dalam bentuk tabel.
Tabel 1

Statistik Deskriptif Rata-Rata Pretes, Posttes, dan Gain Ternormalisasi Kemampuan Penalaran Matematik

\begin{tabular}{|c|c|c|c|c|c|}
\hline \multirow[b]{2}{*}{ Variabel } & \multirow{2}{*}{$\begin{array}{l}\text { Data } \\
\text { Stat }\end{array}$} & \multicolumn{4}{|c|}{ Pendekatan MEAs } \\
\hline & & $\mathbf{N}$ & Pretes & Postes & G \\
\hline \multirow{4}{*}{$\begin{array}{l}\text { Kemampu } \\
\text { an } \\
\text { Penalaran } \\
\text { Matematik }\end{array}$} & $\bar{x}$ & \multirow{4}{*}{26} & 18.81 & 58.46 & 0.49 \\
\hline & $\mathrm{S}$ & & 3.422 & 4.253 & 0.055 \\
\hline & $\mathrm{X}_{\min }$ & & 13 & 46 & 0.35 \\
\hline & $\mathrm{X}_{\max }$ & & 24 & 65 & 0.55 \\
\hline \multirow[b]{2}{*}{ Variabel } & Data & \multicolumn{4}{|c|}{ Pembelajaran Ekspositori } \\
\hline & Stat & $\mathbf{N}$ & Pretes & Postes & $\mathbf{G}$ \\
\hline \multirow{4}{*}{$\begin{array}{l}\text { Kemampu } \\
\text { an } \\
\text { Penalaran } \\
\text { Matematik }\end{array}$} & $\bar{x}$ & \multirow{4}{*}{24} & 18.67 & 56.25 & 0.46 \\
\hline & $S$ & & 3.522 & 4.266 & 0.057 \\
\hline & $X_{\min }$ & & 10 & 46 & 0.35 \\
\hline & $\mathrm{X}_{\max }$ & & 26 & 65 & 0.56 \\
\hline
\end{tabular}

Keterangan: - Skor ideal untuk kemampuan penalaranmatematik adalah 100.

1. Analisis Pretes Kemampuan Penalaran Matematik

a. Uji Normalitas Pretes kemampuan penalaran Matematik

Pengujian normalitas skor pretes dihitung dengan menggunakan program SPSS 22 for windows dengan menggunakan uji ShapiroWilk. Hipotesis yang diuji pada data pretes kemampuan penalaran matematik pada kelas yang menggunakan pembelajaran MEAs dan pembelajaran Ekspositori adalah:

Ho: sampel berasal dari populasi data berdistribusi normal

Ha: sampel berasal dari populasi data tidak berdistribusi normal 
Kriteria pengujian, jika sig. $>\alpha$, maka $\mathrm{Ho}$ ditolak dan jika sig. $<\alpha$, maka Ho diterima, dengan taraf signifikan sebesar $\alpha=0,05$.

\section{Tabel 2}

Uji Normalitas Skor Pre-tes Kemampuan Penalaran Matematik

\begin{tabular}{|c|c|c|c|}
\hline \multirow{2}{*}{ Kelas } & \multicolumn{3}{|c|}{ Shapiro-Wilk } \\
\cline { 2 - 4 } & Statistic & Df & Sig. \\
\hline $\begin{array}{c}\text { Pendekatan } \\
\text { MEAs }\end{array}$ & 0.954 & 26 & 0.338 \\
\hline $\begin{array}{c}\text { Pembelajaran } \\
\text { Ekspositori }\end{array}$ & 0.947 & 24 & 0.234 \\
\hline
\end{tabular}

Jadi, sampel berasal dari populasi data tidak berdistribusi normal.

\section{b. Uji Nonparametrik Mann-Whitney Pre-tes} Kemampuan Penalaran Matematik

Uji statistik berikutnya adalah dengan uji nonparametrik Mann-Whitney yang bertujuan untuk melihat uji perbedaan dua rata-rata skor pretes kemampuan penalaran matematik antara kelas yang pembelajarannya dengan pendekatan MEAs dan pembelajaran Ekspositori.Kriteria pengujiannya adalah Ho diterima jika nilai sig. $>\alpha$ dan Ha ditolak. Sedangkan jika nilai sig. $<\alpha$ maka Ho ditolak dan Ha diterima dengan tingkat signifikansi $\alpha=0,05$. Adapun hipotesis yang diuji adalah:

Ho : $\mu_{1}=\mu_{2}$ : tidak terdapat perbedaan rerata skor pretes antara kemampuan awal penalaran matematik kelas yang menggunakan pendekatan MEAs dan pembelajaran Ekspositori.

$\mathrm{Ha}: \mu_{1} \neq \mu_{2}$ : terdapat perbedaan rerata skor pretes antara kemampuan awal penalaran matematik kelas yang menggunakan pendekatan MEAs dan pembelajaran Ekspositori.

Hasil perhitungan uji Mann-Whitney kemampuan penalaran matematik dapat dilihat pada tabel dibawah ini:

Tabel 3

Uji Mann-Whitney Skor Pretes Kemampuan Penalaran Matematik

\begin{tabular}{|c|c|c|c|}
\hline Kelas & $\mathbf{N}$ & $\begin{array}{c}\text { Mann- } \\
\text { Whitney }\end{array}$ & $\begin{array}{c}\text { Asymp. } \\
\text { Sig. (2- } \\
\text { tailed) }\end{array}$ \\
\hline $\begin{array}{c}\text { Pendekatan } \\
\text { MEAs }\end{array}$ & 26 & \multirow{2}{*}{307.500} & 0.930 \\
\cline { 1 - 2 } $\begin{array}{c}\text { Pembelajaran } \\
\text { Ekspositori }\end{array}$ & 24 & & \\
\hline
\end{tabular}

Tabel 3 di atas memperlihatkan bahwa nilai sig.(2-pihak) > 0,05. Adapun kriteria pengujiannya adalah Ho diterima jika nilai sig. (2-pihak) $>\alpha$, dan yang lainnya $\mathrm{Ha}$ ditolak. Sedangkan jika nilai sig.(2-pihak) $<\alpha$, maka $\mathrm{Ho}$ ditolak, dan yang lainnya $\mathrm{Ha}$ diterima dengan tingkat signifikansi $\alpha=0,05$. Karena nilai sig. (2-pihak $)=0.930$, maka nilai sig.(2-pihak) yang diperoleh lebih dari $\alpha=$ 0,05, sehingga Ho diterima.

Jadi, dapat disimpulkan bahwa untuk pretes kemampuan penalaran matematik mahasiswa kelas dengan pembelajaran MEAs maupun kelas dengan pembelajaran Ekspositori tidak terdapat perbedaan kemampuan awal penalaran matematik di antara kedua kelas tersebut.
2. Analisis Posttes Kemampuan Penalaran Matematik


a. Uji Normalitas Posttes Kemampuan Penalaran Matematik

Pengujian normalitas skor posttest dihitung dengan menggunakan program SPSS 22 for windows dengan menggunakan uji Shapiro-Wilk. Hipotesis yang diuji pada masing-masing data posttest kemampuan penalaran matematik pada kelas eksperimen maupun kelas kontrol adalah:

Ho: sampel berasal dari populasi data berdistribusi normal

Ha: sampel berasal dari populasi data berdistribusi tidak normal

Kriteria pengujian jika sig. $<\alpha$, maka Ho ditolak dan jika sig. $>\alpha$, maka Ho diterima, dengan taraf signifikan sebesar $\alpha$ $=0,05$. Hasil uji normalitas dapat dilihat pada Tabel 4.

Tabel 4

Uji Normalitas Skor Posttes Kemampuan

Penalaran Matematik

\begin{tabular}{|l|l|l|l|}
\hline \multirow{2}{*}{ Kelas } & \multicolumn{3}{|l}{$\begin{array}{l}\text { Kemampuan Penalaran } \\
\text { Matematik }\end{array}$} \\
\cline { 2 - 4 } & \multicolumn{3}{|l}{ Shapiro-Wilk } \\
\cline { 2 - 4 } & Statistic & Df & Sig. \\
\hline $\begin{array}{l}\text { Pendekatan } \\
\text { MEAs }\end{array}$ & 0.925 & 26 & 0.075 \\
\hline $\begin{array}{l}\text { Pembelajaran } \\
\text { Ekspositori }\end{array}$ & 0.949 & 24 & 0.255 \\
\hline
\end{tabular}

Berdasarkan Tabel 4 di atas, uji normalitas skor posttest kemampuan penalaran matematik mahasiswa yang pembelajarannya menggunakan pendekatan MEAs dan pembelajaran Ekspositori dengan Uji Shapiro-Wilk diperoleh nilai Sig. lebih dari nilai $\alpha=0,05$. Ini berarti untuk hipotesis Ho diterima sedangkan Ha ditolak. Jadi, sampel berasal dari populasi data berdistribusi tidak normal. Untuk selanjutnya dilakukan Uji MannWhitney untuk kedua kelompok tersebut.

b. Uji Nonparametrik Mann-Whitney

Posttes Kemampuan Penalaran Matematik

Uji statistik berikutnya yaitu dengan menggunakan uji nonparametrik MannWhitney. Adapun hipotesis yang diuji adalah: "Pencapaian kemampuan penalaran matematik mahasiswa yang menggunakan pendekatan MEAs lebih baik dibandingkan dengan mahasiswa yang menggunakan pembelajaran Ekspositori".

Rumusan hipotesis statistik yang diuji untuk menguji hipotesis yang diajukan di atas adalah:

Ho : $\mu_{1} \leq \mu_{2}$

$\mathrm{Ha}: \mu_{1}>\mu_{2}$

Keterangan:

$\mu_{1}=$ rerata skor posttes kemampuan penalaran matematik yang pembelajaranya menggunakan pendekatan MEAs.

$\mu_{2}=$ rerata skor posttes kemampuan penalaran matematik yang pembelajaranya menggunakan pembelajaran Ekspositori.

Hasil perhitungan uji Mann-Whitney untuk uji rerata skor posttes kemampuan penalaran matematik diperlihatkan pada tabel di bawah ini: 
Tabel 5

Uji Mann-Whitney

Skor Posttest Kemampuan Penalaran Matematik

\begin{tabular}{|l|l|l|l|}
\hline Kelas & N & $\begin{array}{l}\text { Mann- } \\
\text { Whitney }\end{array}$ & $\begin{array}{l}\text { Asymp. } \\
\text { Sig. (2- } \\
\text { tailed) }\end{array}$ \\
\hline $\begin{array}{l}\text { Pendekatan } \\
\text { MEAs }\end{array}$ & 26 & 201.500 & 0.031 \\
\hline $\begin{array}{l}\text { Pembelajaran } \\
\text { Ekspositori }\end{array}$ & 24 & & \\
\hline
\end{tabular}

Tabel 5 di atas memperlihatkan bahwa nilai sig.(2-pihak) $<0,05$. Akan tetapi, uji Mann-Whitney yang digunakan untuk menguji perbedaan rerata skor posttes kemampuan penalaran matematik ini adalah uji satu pihak. Menurut Uyanto (Rohmah, 2009), nilai sig. (1-pihak) $=\frac{1}{2} \times$ sig. (2-pihak) Adapun kriteria pengujiannya adalah Ho diterima jika nilai sig. (1-pihak) $>\alpha$, dan yang lainnya $\mathrm{Ha}$ ditolak. Sedangkan jika nilai sig.(1-pihak) $<\alpha$, maka Ho ditolak, dan yang lainnya $\mathrm{Ha}$ diterima dengan tingkat signifikansi $\alpha=0,05$. Karena nilai sig.(2pihak $)=0,031$, maka nilai sig. $(1-$ pihak $)=\frac{1}{2} x$ $0,031=0,016$. Nilai sig.(1-pihak) yang diperoleh kurang dari $\alpha=0,05$, sehingga Ho ditolak. Artinya pencapaian kemampuan penalaran matematik mahasiswa yang menggunakan pendekatan MEAs lebih baik dibandingkan dengan mahasiswa yang menggunakan pembelajaran Ekspositori.

\section{Analisis Gain Ternormalisasi Kemampuan Penalaran Matematik}

Analisis gain ternormalisasi dimaksudkan untuk melihat peningkatan kemampuan penalaranmatematik mahasiswa yang pembelajarannya menggunakan pendekatan MEAs dan pembelajaran Ekspositori. Data gain ternormalisasi berasal dari selisih skor postes dengan skor pretes dari skor tes kemampuan penalaranmatematik dibagi dengan selisih antara skor maksimum ideal dengan skor pretes.

a. Uji Normalisasi Gain Ternormalisasi Kemampuan Penalaran Matematik

Pengujian normalitas skor gain ternormalisasi dihitung dengan menggunakan program SPSS 22 for windows pada uji Shapiro-Wilk. Hipotesis yang diuji pada masing-masing data gain ternormalisasi kemampuan penalaran matematik pada kelas eksperimen maupun kelas kontrol adalah:

Ho: sampel berasal dari populasi data berdistribusi normal

Ha: sampel berasal dari populasi data berdistribusi tidak normal

Kriteria pengujian, jika sig. $>\alpha$, maka Ho diterima dan jika sig. $<\alpha$, maka Ho ditolak, dengan taraf signifikan sebesar $\alpha=0,05$. 
Tabel 6

Uji Normalitas Skor Gain Ternormalisasi Kemampuan Penalaran Matematik

\begin{tabular}{|l|l|l|l|}
\hline \multirow{2}{*}{ Kelas } & \multicolumn{2}{|l}{$\begin{array}{l}\text { Kemampuan } \\
\text { Matematik }\end{array}$} & \multicolumn{2}{l|}{ Penalaran } \\
\cline { 2 - 4 } & \multicolumn{2}{|l|}{ Shapiro-Wilk } \\
\cline { 2 - 4 } & Satistic & Df & Sig. \\
\hline $\begin{array}{l}\text { Pendekatan } \\
\text { MEAs }\end{array}$ & 0,873 & 26 & 0,006 \\
\hline $\begin{array}{l}\text { Pembelajaran } \\
\text { Ekspositori }\end{array}$ & 0,955 & 24 & 0,353 \\
\hline
\end{tabular}

Dapat dilihat pada Tabel 6, uji normalitas skor gain ternormalisasi kemampuan penalaran matematik mahasiswa yang pembelajarannya menggunakan pendekatan MEAs dan pembelajaran Ekspositori dengan Uji Shapiro-Wilk diperoleh nilai Sig. kurang dari nilai $\alpha=0,05$. Selanjutnya dilakukan Uji Mann-Whitney untuk gain ternormalisasi kemampuan penalaran matematik mahasiswa

b. Uji Mann-Whitney Gain Ternormalisasi

Kemampuan Penalaran Matematik

Uji statistik berikutnya yaitu dengan menggunakan uji nonparametrik MannWhitney. Adapun hipotesis yang diuji adalah: "Peningkatan kemampuan penalaran matematik mahasiswa yang pembelajarannya menggunakan pendekatan MEAs lebih baik dibandingkan dengan mahasiswa yang meggunakan pembelajaran Ekspositori”.

Rumusan hipotesis statistik yang diuji untuk menguji hipotesis yang diajukan di atas adalah:

Ho : $\mu_{1} \leq \mu_{2}$

$\mathrm{Ha}: \mu_{1}>\mu_{2}$

Keterangan: $\mu_{1}=$ rerata skor gain ternormalisasi kemampuan penalaran matematik yang pembelajaranya menggunakan pendekatan MEAs.

$\mu_{2}=$ rerata skor gain ternormalisasi kemampuan penalaran matematik yang pembelajaranya menggunakan pembelajaran Ekspositori.

Hasil perhitungan uji Mann-Whitney skor gain ternormalisasi kemampuan penalaran matematik ini diperlihatkan pada tabel di bawah ini:

Tabel 7

Uji Mann-Whitney Gain Ternormalisasi

Kemampuan Penalaran Matematik

\begin{tabular}{|l|c|l|l|}
\hline Kelas & $\mathrm{N}$ & $\begin{array}{l}\text { Mann- } \\
\text { Whitney }\end{array}$ & $\begin{array}{l}\text { Asymp. } \\
\text { Sig. (2- } \\
\text { tailed) }\end{array}$ \\
\hline $\begin{array}{l}\text { Pendekatan } \\
\text { MEAs }\end{array}$ & 26 & 209.500 & 0.04 \\
\hline $\begin{array}{l}\text { Pembelajaran } \\
\text { Ekspositori }\end{array}$ & 24 & & \\
\hline
\end{tabular}

Tabel 7 di atas memperlihatkan bahwa nilai sig.(2-pihak) $<0,05$. Akan tetapi, uji Mann-Whitney yang digunakan untuk menguji perbedaan rerata skor gain ternormalisasi kemampuan penalaran matematik ini adalah uji satu pihak. Menurut Uyanto (Rohmah, 2009), nilai sig. (1-pihak) $=\frac{1}{2} \mathrm{x}$ sig. (2-pihak). Adapun kriteria pengujiannya adalah Ho diterima jika nilai sig. (1-pihak) $>\alpha$, dan yang lainnya $\mathrm{Ha}$ ditolak. Sedangkan jika nilai sig.(1-pihak) $<\alpha$, maka Ho ditolak, dan yang lainnya $\mathrm{Ha}$ diterima dengan tingkat signifikansi $\alpha=0,05$. Karena nilai sig.(2-pihak) $=0,04$, maka sig.(1-pihak) $=\frac{1}{2} \times 0,04=0,02$. Nilai sig. $(1-$ pihak) yang diperoleh kurang dari $\alpha=0,05$, 
sehingga Ho ditolak. Artinya peningkatan kemampuan penalaran matematik mahasiswa yang pembelajarannya menggunakan pendekatan MEAs lebih baik dibandingkan dengan mahasiswa yang menggunakan pembelajaran Ekspositori.

\section{Pembahasan Hasil Penelitian}

Dari uraian diatas memperjelas bahwa untuk meningkatkan kemampuan penalaran matematik dengan pendekatan MEAs bukan suatu hal yang mudah. Pernyataan tersebut didukung oleh Chamberlin dan Moon (Hanifah, 2016) menyatakan bahwa pada kegiatan Model eliciting activities (MEAs) siswa diminta untuk menyelesaikan permasalahan matematika dengan membuat model matematisnya.

Dengan pendekatan MEAs mahasiswa mencoba menyelesaikan permasalahan matematik dengan cara menghubungkan konsep-konsep yang telah dimiliki sebelumnya dan membiasakan siswa untuk mampu menalar dan menarik kesimpulan dari suatu pernyataan.Berdasarkan pengamatan penulis di lapangan bahwa pembelajaran dengan pendekatan MEAs memiliki kelebihan dalam meningkatkan kemampuan penalaran matematik mahasiwa, karena dalam pendekatan MEAs mendorong mahasiswa aktif berfikir, memberi kesempatan kepada mahasiswa untuk menanyakan hal-hal yang kurang jelas sehingga dosen dapat menjelaskan kembali. Perbedaan pendapat antara mahasiswa dapat dikompromikan atau diarahkan pada suatu diskusi. Pertanyaan yang diajukan dapat menarik dan memusatkan perhatian mahasiswa, dan cara meninjau kembali (review) materi kuliah sebelumnya serta mengembangkan keberanian dan keterampilan mahasiswa dalam menjawab dan mengemukakan pendapat.

Dari analisis data hasil penelitian bahwa pencapaian dan peningkatan kemampuan penalaran matematik mahasiswa yang pembelajarannya menggunakan pendekatan MEAs lebih baik daripada mahasiswa yang pembelajarannya menggunakan pembelajaran Ekspositori.

Penelitian yang relevan dengan penelitian ini antara lain, penelitian yang dilakukan oleh (Lestari, 2016) yang berjudul Meningkatkan Kemampuan Komunikasi dan Berpikir Kreatif Matematis serta Kemandirian Belajar Siswa SMP melalui Pembelajaran Model Eliciting Activities. Kesimpulannya keaktifan mahasiswa pada pembelajaran dengan pendekatan MEAs berpengaruh positif terhadap penalaran matematik mahasiswa.

\section{PENUTUP}

\section{Simpulan}

Berdasarkan hasil analisis data dan pengujian hipotesis, penelitian ini memberi suatu kesimpulan bahwa:

1. Pencapaian kemampuan penalaran matematik mahasiswa yang pembelajarannya menggunakan pembelajaran MEAs lebih baik daripada yang menggunakan pembelajaran ekspositori.

2. Peningkatan kemampuan penalaran matematik mahasiswa yang pembelajarannya menggunakan 
pembelajaran MEAs lebih baik daripada yang menggunakan pembelajaran ekspositori.

\section{Saran}

Berdasarkan temuan dalam penelitian saran-saran yang diajukan penulis adalah: Kelebihan dalam penelitian menggunakan model eliciting activities (MEAs) yaitu membuat Mahasiswa lebih aktif dan berinteraksi dengan dosen sedangkan kekurangannya berkaitan dengan waktu pembelajaran. Pembelajaran matematika dengan pendekatan MEAs dapat dijadikan salah satu alternatif pembelajaran matematik di sekolah atau perguruan tinggi untuk meningkatkan kemampuan penalaran matematik mahasiswa. Penerapan pendekatan MEAs yang lebih efektif hendaknya mempersiapkan sarana belajar yang memadai, misalnya modul, LKM, atau buku sumber secara optimal. Penelitian lebih lanjut hendaknya untuk mengembangkan permasalahan selain yang telah dikaji dalam penelitian ini.

\section{DAFTAR PUSTAKA}

Aini, I. (2013). Meningkatkan Literasi Matematis Siswa Melalui Pendekatan Keterampilan Proses Matematis.Tesis Pendidikan Matematika Universitas Pendidikan Indonesia. Bandung: Tidak diterbitkan.

Hanifah. (2017). Penerapan Pembelajaran Model Eliciting Activities (MEA) dengan Pendekatan Saintifik untuk Meningkatkan Kemampuan Pemecahan Masalah Matematis Siswa. Prosiding Senamas 2017. Makasar
Lestari, K, dan Yudhanegara, M. (2015). Penelitian Pendidikan Matematik. Bandung: Refika Aditama.

Lestari, K. (2016). Meningkatkan Kemampuan Komunikasi dan Berpikir Kreatif Matematis serta Kemandirian Belajar Siswa SMP melalui Pembelajaran Model Eliciting Activities. Tesis STKIP Siliwangi. Bandung: Tidak diterbitkan.

Setyono (2008). Peningkatan Kemampuan Penalaran Siswa dalam Pembelajaran Matematika. Skripsi Sarjana Pendidikan Matematika STKIPSubang: Tidak diterbitkan.

Suherman, Erman. (2003). Evaluasi Pembelajaran Matematika. Bandung: JICA-UPI Bandung.

Suherman, Erman.,et.al. (2003). Strategi Pembelajaran Matematika Komtemporer. Bandung: JICA-UPI Bandung.

Sumarmo, Utari. (2013). Berpikir dan Disposisi Matematik serta Pembelajarannya. Bandung: Universitas Pendidikan Indonesia.

Sumarmo, U. (2013). Penilaian Pembelajaran Matematika. Bandung: Refika Aditama.

Zulkarnaen, R (2015). Pengaruh Model Eliciting Activities (MEAs) terhadap Kreativitas Matematis pada Siswa Kelas VIII pada Satu Sekolah di Kabupaten Karawang.Jurnal IImiah Program Studi Matematika STKIP Siliwangi Bandung. Vol 4, No.1, Februari 2015. 